\title{
Graham Johnston: Bringing Success to Neuroscience Through Medicinal Chemistry
}

\author{
Philip M. Beart · Vladimir J. Balcar
}

Accepted: 15 May 2009/Published online: 30 May 2009

(C) Springer Science+Business Media, LLC 2009

As the first two of Professor Graham Johnston's graduate students, we are delighted to be guest editors of this special issue of Neurochemical Research honouring his distinguished career. Graham was a member of the Editorial Board of Neurochemical Research (1978-1987), the first Australian to be a member of the Council of the International Society for Neurochemistry (1977-1981) and the founding President of the Asian Pacific Society for Neurochemistry (1991-1994).

Graham's 70th birthday in June 2009 represents a suitable occasion to reflect upon the career of one of Australia's most renowned and internationally well known biomedical scientists. His research efforts have not only greatly advanced our understanding of the amino acid neurotransmitters, GABA, glycine and L-glutamate, but were instrumental in their acceptance as major transmitters of the mammalian brain. However, what stands out from a publication list of some 400 papers is how his unique chemical insights have led to idiosyncratic and totally unexpected advances in neuroscience. Indeed his

\section{P. M. Beart ( $\square)$}

Molecular Neuropharmacology, Florey Neuroscience Institutes, University of Melbourne, NNF2, Alan Gilbert Building,

Melbourne, VIC 3010, Australia

e-mail: philip.beart@florey.edu.au

P. M. Beart

Department of Pharmacology, University of Melbourne, NNF2, Alan Gilbert Building, Melbourne, VIC 3010, Australia

\section{J. Balcar}

Laboratory of Neurochemistry, Discipline of Anatomy and Histology, Bosch Institute and School of Medical Sciences Sydney Medical School, University of Sydney, Sydney, NSW 2006, Australia contributions should probably be viewed within the broadest context of "chemical" neuroscience.

Graham's early career was influenced by three outstanding scientists - all Fellows of the Royal Society (UK) and the latter two were Nobel laureates: C.W. Shoppee (MSc supervisor at University of Sydney, 1959-1961), Lord Todd (PhD supervisor at University of Cambridge, 1961-1964) and M. Calvin (postdoctoral supervisor at University of California at Berkeley, 1964-1965). Here we recognise seminal periods of training involving organic chemistry focused on biological function and pharmacological activity. His interest in neurochemistry and neurochemical pharmacology was stimulated by Jeff Watkins (of NMDA fame, later FRS), an earlier Cantabrigian PhD graduate from Todd's laboratory, that led to Graham replacing Watkins at the John Curtin School of Medical Research, Australian National University, and working on amino acids. Here he established medicinal chemistry and neurochemical laboratories, and collaborated (1965-1980) with David Curtis (later FRS) in the Department of Physiology made famous by the Nobel Prize Winner, Sir John Eccles. Indeed, it remains one of his favourite expressions that all his students were duly entitled to be considered as descended from the "Ecclesiastical" line-this witticism appropriately illustrates his sharp, and at times wry sense of humour, often not appreciated by the unsuspecting. By the time he undertook study leave (1970-1971) at the University of Cambridge with Les Iversen (later FRS) his career had undergone a meteoric rise with the description of strychnine and bicuculline as glycine and GABA antagonists, respectively. We both remember well Graham's return from working with Iversen, excited about transporters for amino acid transmitters, ordering a McIlwain Tissue Chopper and launching projects in this area. Neurochemical work of this type, in 
concert with medicinal chemistry, continued with great success at the University of Sydney where he was appointed to the Chair of Pharmacology (1980-present) and established the Adrien Albert Laboratory of Medicinal Chemistry (1990).

Graham's contributions to neurochemistry are very broad and focus mainly on aspects of the biology of receptors and transporters for GABA, glycine and L-glutamate. We should not forget that many of these seminal advances pre-dated the cloning, sequencing and structure determination of these diverse proteins. Three publications [1-3] are listed in the Science Citation index as Citation Classics. Of special note are many publications defining the neurochemistry and pharmacology of GABA receptors, which he defined as "simple as A, B, C" [4]. Many early studies addressed the properties of steroid, barbiturate and benzodiazepine sites of the $\mathrm{GABA}_{\mathrm{A}}$ receptor, for which he demonstrated some of the early links to stress [5]. We cannot but speculate whether Graham's continued interest in the actions of therapeutically beneficial, dietary flavonoids at the $\mathrm{GABA}_{\mathrm{A}}$ receptor is fuelled by a love of fine food and wine [6, 7]. More recently his work has led to the definition of the $\mathrm{GABA}_{\mathrm{C}}$ receptor [8], which appears to represent a therapeutic target for myopia and in enhancing cognition and in managing memory-related disorders [9]. Other early studies showed the way towards defining the multiple subtypes of ionotropic receptors for L-glutamate [10, 11]. For Graham, neurochemistry always went hand-in-hand with medicinal chemistry, and the synthesis and pharmacological evaluation of new ligands. Indeed, many compounds used routinely in amino acid pharmacology were introduced and/or synthesised by Graham and his collaborators: muscimol, bicuculline, nipecotic acid, 2-hydroxy-saclofen, $\left[{ }^{3} \mathrm{H}\right]_{\mathrm{D}-\text { aspartate, threo- }}$ 3-hydroxyaspartate, 4-methylglutamate and cis-4-aminocrotonic acid. Structure-activity relationships and medicinal chemistry have been continuing passions, with current efforts directed at new chemical entities for the management of anxiety, epilepsy and memory disorders.

Along with major scientific milestones, there have been receipts of prestigious lectureships at international and national scientific congresses, and other recognition of diverse achievements including medals. Graham has served many learned Societies with great distinction across various disciplines (neuroscience, pharmacology and chemistry). He is a Fellow of the Australian Academy of Technological Sciences and Engineering (1993) and the International Union of Pure and Applied Chemistry (2002), and received a Doctor Pharmaciae honoris causa (University of Copenhagen, 2007). His award of Membership,
Order of Australia (1998), noted services to bio-organic chemistry and pharmacology, and to scientific organisations and to science policy development (as President of the Federation of Australian Scientific and Technological Societies). A highlight of his long record of service to the Australian public is his membership of the Administrative Appeals Tribunal of the Commonwealth of Australia since 1991. Those who know Graham well are aware of his role as a vocal advocate and a voice for reason in many arenas, be they academic, biomedical or science policy. His determination, doggedness and commitment to many causes, ideas and viewpoints, especially those of a more unpopular nature, are well remembered by many of us. Graham has had a continuing passion for good science and for life throughout his distinguished career. His passions outside science include, travel, good food and wine, tennis and skiing, all enjoyed with his wonderful wife, Helen.

\section{References}

1. Curtis DR, Johnston GAR (1974) Amino acid transmitters in the mammalian central nervous system. Rev Physiol 69:97-188

2. Curtis DR, Duggan AW, Felix D, Johnston GAR (1971) Bicuculline, an antagonist of GABA and synaptic inhibition in the spinal cord. Brain Res 32:69-96

3. Balcar VJ, Johnston GAR (1972) The structural specificity of the high affinity uptake of L-glutamate and L-aspartate by rat brain slices. J Neurochem 19:2657-2666

4. Chebib M, Johnston GAR (1999) The 'ABC' of GABA receptors: a brief review. Clin Exp Pharmacol Physiol 26:937-940

5. Skerritt JH, Trisdikoon P, Johnston GAR (1981) Increased GABA binding in mouse brain following acute swim stress. Brain Res 215:398-403

6. Johnston GAR, Beart PM (2004) Flavonoids: some of the wisdom of sage? Br J Pharmacol 142:809-810

7. Fernandez SP, Mewett KN, Hanrahan JR, Chebib M, Johnston GAR (2008) Flavan-3-ol derivatives are positive modulators of $\mathrm{GABA}_{\mathrm{A}}$ receptors with higher efficacy for the $\alpha_{2}$ subtype and anxiolytic action in mice. Neuropharmacology 55:900-907

8. Johnston GAR (1996) GABA-C receptors: relatively simple transmitter-gated ion channels? Trends Pharmacol Sci 17: 319-323

9. Chebib M, Hinton T, Schmid KL, Brinkworth D, Qian H, Matos S, Kim HL, Abdel-Halim H, Kumar RJ, Johnston GAR, Hanrahan JR (2009) Novel, potent, and selective GABA $_{C}$ antagonists inhibit myopia development and facilitate learning and memory. J Pharmacol Exp Ther 328:448-457

10. Duggan AW, Johnston GAR (1970) Glutamate and related amino acids in cat spinal roots, dorsal root ganglia and peripheral nerves. J Neurochem 17:1205-1208

11. McCulloch RM, Johnston GAR, Game CJ, Curtis DR (1974) The differential sensitivity of spinal interneurones and Renshaw cells to kainate and N-methyl-D-aspartate. Exp Brain Res 21:515-518 